\title{
Soymilk as a Novel Milk Replacer to Stimulate Early Calf Starter Intake and Reduce Weaning Age and Costs
}

\author{
G. R. Ghorbani, ${ }^{*}$ R. Kowsar, ${ }^{*}$ M. Alikhani, ${ }^{*}$ and A. Nikkhah ${ }^{1,2}$ \\ *Department of Animal Science, Isfahan University of Technology, Isfahan 84156 Iran \\ †Department of Animal Science, University of Manitoba, Winnipeg, MB, R3T 2N2 Canada
}

\section{ABSTRACT}

The primary objective was to determine the effects of partial replacement of whole milk with soymilk on preweaning calf performance and weaning costs. Following $3 \mathrm{~d}$ of colostrum and transition milk feeding, 18 male and 9 female neonatal Holstein calves $(41.6 \pm 1.6 \mathrm{~kg}$ of body weight; mean $\pm \mathrm{SE}$ ) were assigned in a completely randomized design to 3 treatments offered at $10 \%$ of body weight (wet basis) including 1) whole milk (control), 2) $75 \%$ whole milk $+25 \%$ soymilk (S25), or 3 ) $50 \%$ whole milk $+50 \%$ soymilk (S50). The weaning criterion was defined as the calf age at a daily intake of $\geq 900 \mathrm{~g}$ of starter concentrate. During the first 2 wk of the experiment, treatments did not differ in starter intake and fecal score. Calves fed S25 gained similar amount of body weight as calves fed whole milk diet. By $49 \mathrm{~d}$ of age, also, calves on S25 gained similar body weight as did calves on whole milk diet. Calves on S25 and S50 achieved the weaning criterion, respectively, about 10 and $12 \mathrm{~d}$ earlier than did peers on whole milk. The soymilk-fed calves consumed less milk than control calves to meet the weaning criterion owing to promoted starter intake. Feed-related weaning costs dropped by about 35\% when soymilk was fed because whole milk was about 50\% more expensive than both soymilk and starter concentrate. Feeding soymilk at up to $50 \%$ of the milk diet maintained health during the first 2 to $4 \mathrm{wk}$ of age when the neonate calf is highly sensitive to nonmilk proteins and plant antinutrients. Results introduce soymilk as an economic partial substitute for whole milk in calf-raising facilities.

Key words: calf, soymilk, starter, weaning

Received June 10, 2007.

Accepted August 22, 2007

${ }^{1}$ Corresponding author: anikkhah@uiuc.edu

Note: Corresponding author's e-mail address changed in this corrected paper.

${ }^{2}$ Current address: Dept. Animal Sciences, University of Illinois, Urbana, 61801.

\section{INTRODUCTION}

Any strategy that can stimulate early starter intake in dairy facilities without compromising calf health will reduce weaning age and costs (NRC, 2001). Neonate calves possess little activity of starch and nonstarch carbohydrases and proteinases (Van Soest, 1994). An adequate and early supply of moderately fermentable dry feed is necessary for the timely establishment of amylolytic, fibrolytic, and proteolytic capacities in the reticulorumen (Sander et al., 1959; Maiga et al., 1994; Van Soest, 1994). Early reticulorumen development will subsequently lower weaning age, save milk, and reduce feed and labor costs (Anderson et al., 1987; NRC, 2001). Soy protein sources such as soy protein concentrate and soy protein isolate have partly been used in milk replacers (Silva et al., 1986; Drackley et al., 2006). Soy protein preparations, however, contain antigenic and phenolic compounds which adversely affect intestinal integrity and calf growth during the first 2 to 4 wk of life (Gardner et al., 1990; Lallès et al., 1995a,b; Drackley et al., 2006).

The dairy industry, particularly in regions where weaning occurs late, is in much need of economical milk replacers that can maintain normal calf health during the first 2 to 4 wk of age and make calf-raising more profitable. Soymilk is cheaper and contains less protein and fat compared with milk (NutritionData, 2007). We propose that due to the lower nutrient content of soymilk than whole milk, its partial substitution for whole milk will drive calf appetite toward dry starter, will stimulate butyrate and propionate production, and will thereby hasten reticulorumen development (Sander et al., 1959; Baldwin et al., 2004). The faster reticulorumen development will enable early weaning and reduce calf-raising costs (Davis and Drackley, 1998). In addition, timely weaning will improve calf health (NRC, 2001). Our principal objective was to determine the effects of partial replacement of whole milk with soymilk on preweaning calf performance and feed-related weaning costs.

\section{MATERIALS AND METHODS}

\section{Experimental Design, Calves, and Treatments}

Eighteen male and nine female neonate Holstein calves with $\mathrm{BW}$ of $41.6 \pm 1.6 \mathrm{~kg}$ (mean $\pm \mathrm{SE})$ were used 
Table 1. Feed ingredients and chemical composition of the calf starter concentrate (DM basis)

\begin{tabular}{|c|c|}
\hline Ingredient & $\%$ \\
\hline Ground barley grain & 18.0 \\
\hline Ground corn grain & 36.5 \\
\hline Solvent soybean meal & 34.0 \\
\hline Wheat bran & 6.0 \\
\hline Alfalfa meal & 2.0 \\
\hline Anzymite $^{1}$ & 1.5 \\
\hline Mineral and vitamin supplement ${ }^{2}$ & 0.5 \\
\hline Dicalcium phosphate & 1.5 \\
\hline \multicolumn{2}{|l|}{ Chemical composition } \\
\hline Dry matter & 88.2 \\
\hline $\mathrm{NE}_{\mathrm{M}},{ }^{3} \mathrm{Mcal} / \mathrm{kg}$ & 2.2 \\
\hline $\mathrm{NE}_{\mathrm{G}},{ }^{3} \mathrm{Mcal} / \mathrm{kg}$ & 1.8 \\
\hline $\mathrm{CP}$ & 20.7 \\
\hline Acid detergent fiber & 8.2 \\
\hline $\mathrm{NFC}^{4}$ & 50.8 \\
\hline Ether extract & 4.9 \\
\hline Ash & 5.6 \\
\hline
\end{tabular}

\footnotetext{
${ }^{1}$ Ansymite (Afrand Tusca Co., Tehran, Iran) was a crystalline hydrated aluminosilicate containing $90 \%$ clinoptilolite with $67.2 \% \mathrm{SiO}_{2}$, $11.3 \% \mathrm{Al}_{2} \mathrm{O}_{3}, 1.5 \% \mathrm{~K}_{2} \mathrm{O}, 1.8 \% \mathrm{Na}_{2} \mathrm{O}, 3.3 \% \mathrm{CaO}, 0.8 \% \mathrm{MgO}, 0.5 \% \mathrm{TiO}_{2}$, $0.06 \% \mathrm{MnO}, 0.01 \% \mathrm{P}_{2} \mathrm{O}_{5}$. The cation exchange capacity $(\mathrm{CEC})=170$ to $200 \mathrm{mEq} / 100 \mathrm{~g}$.

${ }^{2}$ Contained 250,000 IU of vitamin A, 50,000 IU of vitamin D, 1,500 IU of vitamin E, $2.25 \mathrm{~g}$ of $\mathrm{Mn}, 120 \mathrm{~g}$ of $\mathrm{Ca}, 7.7 \mathrm{~g}$ of $\mathrm{Zn}, 20 \mathrm{~g}$ of $\mathrm{P}$, $20.5 \mathrm{~g}$ of $\mathrm{Mg}, 186 \mathrm{~g}$ of $\mathrm{Na}, 1.25 \mathrm{~F}, 3 \mathrm{~g}$ of S, $14 \mathrm{mg}$ of $\mathrm{Co}, 1.25 \mathrm{~g}$ of $\mathrm{Cu}$, $56 \mathrm{mg}$ of I, and $10 \mathrm{mg}$ of Se per $\mathrm{kg}$ of supplement.

${ }^{3}$ Calculated from NRC (2001).

${ }^{4} 100-(\% \mathrm{NDF}+\% \mathrm{CP}+\%$ ether extract $+\% \mathrm{ash})$.
}

in a completely randomized design (within each sex), with repeated measures. Upon separation from dam, calves were transferred into individual hutches $(1.5 \times$ $1.12 \times 1.2 \mathrm{~m}$ ) bedded with clean wheat straw. The individual hutches were located outdoors, were made of metal and cement, and had an exercise area $(1.2 \times 2.1$ $\mathrm{m})$. The new bedding was added daily as much as required for individual hutches, and when necessary, was entirely cleaned and disinfected using sovlorin cetrimide-C $(1.5 \% \mathrm{wt} / \mathrm{vol}$ clorohexidin glucoronate and $15 \%$ wt/vol cetrimide; Damloran Co., Boroojerd, Iran). The calves were fed colostrum and transition milk for $3 \mathrm{~d}$ at $10 \%$ of BW, and then were randomly assigned to 3 treatments. The treatments were feeding 1 ) whole milk (M), 2) $25 \%$ soymilk + 75\% M (S25), or 3) $50 \% \mathrm{M}+50 \%$ soymilk (S50), at $10 \%$ of BW (wet basis). Calves were assigned to treatments such that each treatment had 3 female and 6 male calves. The treatments were offered twice daily at 1330 and $2030 \mathrm{~h}$. Refrigerated soymilk was heated to 39 to $40^{\circ} \mathrm{C}$ before mixing with milk and delivering to the calves. The weaning criterion was defined as the calf age at a minimum daily starter intake of $\geq 900 \mathrm{~g}$ for 2 consecutive weeks, or additionally, as the calf age at a minimum BW of $70 \mathrm{~kg}$. Calves had unlimited access to a starter concentrate (Table 1) and fresh water. The animals were cared for according to the guidelines of the Iranian Council of Animal Care
(1995). This study was conducted at the calf raising facilities of the Lavark Research Station (Isfahan University of Technology, Isfahan, Iran) from August through November 2006. The average air temperature was $19.4 \pm 8.2^{\circ} \mathrm{C}$, and relative humidity was $42 \pm 11 \%$ during the study.

\section{Soymilk Production and Preparation}

Soybeans were initially sifted, cleaned, and washed using regular water. The washed beans were soaked in deionized water for $18 \mathrm{~h}$ and were cooked by heating up to $98^{\circ} \mathrm{C}$ for $10 \mathrm{~min}$. The cooked product was subsequently fractured and mixed with water using a homogenizer. The homogenate was centrifuged (model 5200 Pieralisi, Sambuca Val di Pesa, Italy) at $3,450 \times g$ to extract soymilk and separate the major protein concentrate. The extracted soymilk was transferred into a storage tank and exposed to vacuum $(640 \mathrm{mmHg})$ under steam pressure (2.5 to $3 \mathrm{mmHg}$ ). The resultant soymilk was deodorized, decontaminated, and finally pasteurized at $78^{\circ} \mathrm{C}$ before use.

\section{On-Farm and Laboratory Measurements}

Calves were weighed weekly shortly before the afternoon milk delivery. Feces were scored for physical shape and consistency with the scores of $1=$ firm, $2=$ slightly loose, 3 = loose, and $4=$ watery. The daily amount of starter offered and orts were recorded for each calf and DM content was determined by ovendrying at $60^{\circ} \mathrm{C}$ for $48 \mathrm{~h}$. Feed was sampled every $2 \mathrm{wk}$ and analyzed for $\mathrm{DM}$, ash (at $500^{\circ} \mathrm{C}$ overnight), NDF (Van Soest et al., 1991; using heat-stable alpha-amylase), and ADF (AOAC, 1997). Soymilk was analyzed for CP (Kjeltech, Auto 1030 Analyzer, Höganäs, Sweden), ether extract (AOAC, 1997), and DM (Freeze Drier FDAmitamura Riken Kogoyo Inc., Ogawa Seiki Co. Ltd., Tokyo, Japan). Whole milk was analyzed for protein, fat, and solids using an infrared analyzer (Milk-O-Scan 133B, Foss Electric, Hillerød, Denmark). Whole milk and soymilk were also analyzed for calcium (titration method) and phosphorous (UV 2100-VIS Spectrophotometer Shimadzu, Kyoto, Japan). The DM, CP, total fat, ash, calcium, and phosphorous contents were, respectively, $12.0,25.0,33.3,5.8,1.0$, and $0.8 \%$ for whole milk; and 9.8, 18.3, 0.5, 6.7, 1.0, and $0.20 \%$ for soymilk (DM basis).

\section{Statistical Analysis}

Data were analyzed as a linear mixed model using PROC MIXED of SAS Institute (SAS Institute Inc., 2003). Final models included the fixed effects of treatment and sex and the random effect of calf. For the 
Table 2. Calf performance on only whole milk (M) or 75\% whole milk $+25 \%$ soymilk (S25) or 50\% whole milk $+50 \%$ soymilk (S50) for 2 wk after the beginning of the trial as well as through $49 \mathrm{~d}$ of age ${ }^{1}$



\footnotetext{
${ }^{1}$ Whole milk was replaced with soymilk on a wet basis.

${ }^{2}$ Beginning of the treatment application.

${ }^{3}$ Given based on physical appearance of feces: $1=$ firm, $2=$ slightly loose, $3=$ loose, $4=$ watery.
}

repeated weekly measures, the models producing the least Akaike's information criterion were adopted (Wang and Goonewardene, 2004). The least square means estimation method was restricted maximum likelihood, and the method of calculating the denominator degrees of freedom was Kenward-Roger (SAS Institute Inc., 2003). The effect of sex was insignificant ( $P$ $>0.10)$. The significant treatment differences were declared at $P<0.05$ and trends at $P<0.10$. Results were presented as least square means \pm standard errors of mean differences.

\section{RESULTS AND DISCUSSION}

Two weeks after the beginning of the full treatment application or at wk 3 of calf age, there were no significant differences between $\mathrm{M}$ and $\mathrm{S} 25$ groups $(P=0.75)$ or between $\mathrm{M}$ and S50 groups $(P=0.32)$ in starter concentrate intake. The total DMI of the starter concentrate plus liquid feed was greater $(P<0.05)$ in calves fed either M or S25 than in calves fed S50 (Table 2). The M and S25 groups, however, did not differ $(P=$ 0.83 ) in total DMI in the forms of dry plus liquid feeds. The lower total DMI of the S50 group was not unexpected because the DM content of soymilk was lower than M. Also, the S50 calves had numerically lower starter intake compared with other calves during the first 2 wk (Table 2). Because of the higher total DMI, average daily gain was also higher in the $\mathrm{S} 25(P=0.01)$ and $\mathrm{M}(P<0.01)$ calves than in the S50 calves (Table 2 ). The M, S25, and S50 calves consumed about 5.82, 5.56 , and $5.71 \mathrm{~kg}$ of $\mathrm{DM}$, respectively, in the form of liquid feed, during the first $14 \mathrm{~d}$ of the experiment. Additionally, whole milk contained $25.0 \% \mathrm{CP}$ and $33.3 \%$ fat, on a DM basis, compared with 18.3 and $0.5 \%$ in soymilk. As a result, the offer of protein and fat in the form of liquid feed were, respectively, 1.46 and $1.94 \mathrm{~kg}$ in the $\mathrm{M}$ calves, 1.30 and $1.40 \mathrm{~kg}$ in the $\mathrm{S} 25$ calves, and 1.24 and $0.97 \mathrm{~kg}$ in the $\mathrm{S} 50$ calves. This means that S50 calves consumed about 15 and 50\% less CP and fat, respectively, than did the $\mathrm{M}$ calves and about 5 and $30 \%$ less CP and fat compared with the S25 calves. Whereas the average daily gain was comparable between the S25 and M calves, the BW gain over the first 2 wk of the trial in the S50 calves was only about 20 to $27 \%$ of the BW gain in the S25 and M calves (Table 2 ). Thus, given the reduced offer of nitrogen and energy in the form of liquid feed, the S50 group expected to gain less BW than M and S25 groups. Reduced protein intake would be important because essential amino acids intake is considered critical in early calf growth. In addition to its relatively lower $\mathrm{CP}$, soymilk usually contains less than one-third of the amount of Lys, Met + Cys, Tyr, and Val compared with whole milk (NutritionData, 2007). This may have contributed to reduced growth rate in the $\mathrm{S} 50$ group during the first $2 \mathrm{wk}$ of the study. However, it should be noted that the reduced nutrient intake in the S50 group was not due to palatability but was attributed to the experimental design. Whole milk was replaced with $50 \%$ soymilk on a wet basis regardless of its nutrient content. This enabled the study to examine the proposal that partial replacement of whole milk with soymilk (possessing fewer nutrients than whole milk per unit of liquid) drives calf appetite toward dry feed and stimulates early starter intake. This theory was proved later by the fact that soymilk-fed calves achieved the weaning criterion earlier than calves on whole milk (Table 3).

The current study demonstrates that soymilk can partially replace whole milk during the few first weeks 
Table 3. Calf performance until weaning or a minimum daily intake of $900 \mathrm{~g}$ of starter concentrate for 2 wk in calves offered, at $10 \%$ of BW, only whole milk (M), $75 \% \mathrm{M}+25 \%$ soymilk (S25), or $50 \% \mathrm{M}+50 \%$ soymilk (S50) ${ }^{1}$

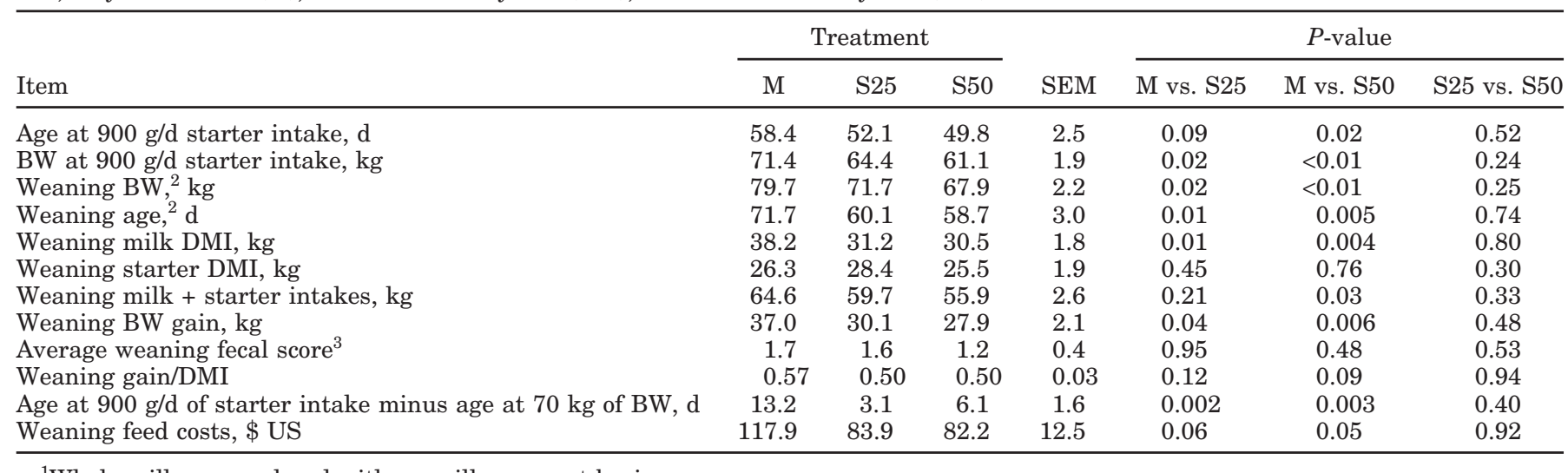

${ }^{1}$ Whole milk was replaced with soymilk on a wet basis.

${ }^{2}$ When a daily starter intake of $\geq 900 \mathrm{~g} / \mathrm{d}$ was attained consistently for 2 consecutive weeks.

${ }^{3}$ Given weekly until weaning based on physical appearance of feces: $1=$ firm, $2=$ slightly loose, $3=$ loose and $4=$ watery.

of age, when the young calf is sensitive to antinutrients and plant proteins. The smooth adaptation of young calves to a particular feeding strategy is essential to maintain calf well-being during the early stages of rumen development (Davis and Drackley, 1998). From a health perspective, the priority would be given to a milk replacer that can facilitate calf transition from whole milk into dry feed without compromising gut integrity and general calf well-being. Calves may not be able to utilize soy protein concentrate and soy flour as effectively in the first few weeks of age as do they later on (Akinyele and Harshbarger, 1983). The first few weeks after birth are thus a critical phase because the neonate calf is sensitive to bacterial and viral stressors. Additionally, young calves are susceptible to the adverse effects of soy antinutrients on the intestinal epithelial health and tissue growth and exhibit a humoral immune response to soy antigens (Dawson et al., 1988). Meanwhile, the young nonrumen digester has to gradually develop into a functioning fermentor (Davis and Drackley, 1998). Such critical transition in the physiology of the gastrointestinal tract and liver will occur in a timely manner only if easily fermentable dry feed is consumed adequately (Heinrichs and Lesmeister, 2005). The sufficient supply of starch with moderate degradability and fermentable cell walls will provide propionate and butyrate, which are necessary for the expansion of the rumen epithelium and hepatic VFA metabolism (Anderson et al., 1987; Maiga et al., 1994; Baldwin et al., 2004). From our data, therefore, we suggest that replacing $25 \%$ rather than $50 \%$ of whole milk with soymilk may be the optimum use of soymilk as a milk replacer during the first 2 to 3 wk of age.

Efficiency of feed use for gain (ratio of BW to DMI) was greater $(P=0.01)$ in $\mathrm{S} 25$ and M groups than in the
S50 group (Table 2). Notably, reduced calf growth in the S50 group was due to reduced offer of nutrients. Feeding soy protein concentrate during the first $2 \mathrm{wk}$ of age has reduced weight gain and feed conversion by about 30\% (Tomkins et al., 1994). The incidence of diarrhea did not differ among treatments (Table 2). Thus, even though nutrient intake was lower for S50, calf health was maintained even with $50 \%$ replacement of whole milk with soymilk. These data support the proposal that soymilk can overcome the limitations of soy protein concentrate and soy protein isolate in maintaining lower gut health and promoting early growth in neonatal calves (Ramsay and Willard, 1975; Lallès et al., 1995b). Despite heat and ethanol treatment (Sissons et al., 1979, 1982), soy-based milk replacers still may adversely affect intestinal health (Kilshaw and Slade, 1982; Dawson et al., 1988) and early calf growth (Drackley et al., 2006). Thus, maintained starter intake and calf growth along with unaffected fecal score suggest that such known and unknown antinutritive antigens, usually found in soy flour (Kilshaw and Slade, 1982), may have been mostly separated or inactivated during the soymilk extraction process.

By 50 to $60 \mathrm{~d}$ of age, calves would possess a welldeveloped reticulorumen fermentation if adequate dry feed is consumed. This suggests that the success of a feeding strategy in alleviating the calf transition from a nonruminant to a ruminant can be assessed at about this age (Yaghoubi et al., 2007). Body weight at $49 \mathrm{~d}$ of age was numerically higher in the S25 $(P=0.11)$ and $\mathrm{M}(P=0.07)$ groups than in the S50 group. These differences were due to the numerical rises in the $\mathrm{ADG}$ of the S50 fed calves compared with the S25 $(P=0.13)$ and $\mathrm{M}(P=0.12)$ fed calves (Table 3$)$. These findings suggest that replacing $25 \%$ of whole milk with soymilk 
did not affect calf growth during the time when the calf is usually about to be weaned. Even the S25 fed calves consumed about $5 \mathrm{~kg}$ more DM than did the M and S50 fed calves, although this difference was not statistically significant (Table 3). The reasonably high intake of the starter concentrate by the S25 group indicated that soymilk can be fed to preweaning calves to promote dry feed intake. This indication was supported by the comparable feed efficiency $(P>0.25)$ among treatments (Table 3).

The S25 $(P=0.09)$ and S50 $(P=0.02)$ fed calves achieved a minimum daily starter intake of $900 \mathrm{~g}$ earlier than did the M group (Table 3). As a result, the BW of the S25 $(P=0.02)$ and S50 $(P<0.01)$ fed calves was lower than the $\mathrm{M}$ fed calves when the weaning criterion was met (Table 3 ). When a consistent daily intake of $900 \mathrm{~g}$ of starter concentrate occurred, the M group was on average $71.7 \mathrm{~d}$ old, whereas the $\mathrm{S} 25$ group was 60.1 $\mathrm{d}$ old $(P=0.01)$ and the S50 group was $58.7 \mathrm{~d}$ old $(P<$ 0.01 ). These data show that partial replacement of whole milk with soymilk stimulated an earlier starter intake. Consequently, total DMI obtained from the liquid food was lower $(P<0.01)$ in soymilk fed calves than in control calves (Table 3). Because the soymilk fed calves increased their starter intake earlier than control calves, total weaning starter intake remained comparable among treatments $(P>0.30$; Table 3$)$. This means that the $\mathrm{M}$ group required 7.0 and $7.7 \mathrm{~kg}$ more liquid feed to meet the weaning criterion, compared with the S25 $(P=0.01)$ and S50 $(P<0.01)$ groups, respectively. This finding is consistent with the notion that partial replacement of whole milk with soymilk reduces milk consumption in favor of stimulating earlier starter intake. Because of the higher and earlier intake of the starter concentrate, and thus the earlier weaning age, weaning was made possible more economically in the $\mathrm{S} 25(P=0.06)$ and $\mathrm{S} 50(P=0.05)$ groups, compared with the M group (Table 3). Such early starter intake and weaning did not affect fecal consistency. This was evident in the comparable fecal score $(P>$ 0.45 ) among all calves.

Feeding calves only whole milk led them to achieve the minimum starter intake of $900 \mathrm{~g} / \mathrm{d}$ much later $(P$ $<0.01$ ) than achieving a BW of $70 \mathrm{~kg}$, compared with soymilk fed calves. This suggests that prolonged milk feeding is uneconomical if an adequate starter intake for the less-stressful weaning could be attained earlier. The earlier starter intake will subsequently reduce calf dependence on milk and calf-raising costs. The profits would increase even more when starter concentrate and soymilk are considerably cheaper than whole milk, as was the case in the current study. The cost of soymilk and the starter was $\$ 0.22$ per $\mathrm{kg}$, but whole milk was $\$ 0.33$ per kg. This along with the earlier starter intake led weaning to occur more economically in the S25 (\$83.9) and S50 (\$82.2) groups than in the M group (\$117.9). It is notable that these reductions in weaning costs did not include the savings due to reduced maintenance, housing, and labor.

\section{CONCLUSIONS}

Replacing 25 and $50 \%$ of whole milk with soymilk promoted early starter intake and enabled early weaning. The stimulated starter intake reduced weaning costs by about $35 \%$ because whole milk was about $50 \%$ more expensive than the starter feed and soymilk. Therefore, economic benefits were attained by partial replacement of whole milk with soymilk without compromising health status of the calves. Findings introduce soymilk as an economic partial substitute for whole milk in calf-raising facilities.

\section{ACKNOWLEDGMENTS}

The authors wish to thankfully acknowledge Isfahan University of Technology (IUT, Isfahan, Iran) for financial support and teaching and research services, the staff at Lavark Research Station (IUT) for diligent animal care, and David Zartman (Ohio State University) for views on an earlier version of the manuscript.

\section{REFERENCES}

Akinyele, I. O., and K. E. Harshbarger. 1983. Performance of young calves fed soybean protein replacers. J. Dairy Sci. 66:825-832.

Anderson, K. L., T. G. Nagaraja, and J. L. Morrill. 1987. Ruminal and metabolic development in calves weaned conventionally or early. J. Dairy Sci. 70:1000-1005.

Association of Official Analytical Chemists. 1997. Official Methods of Analysis. 16th ed. AOAC, Arlington, VA.

Baldwin, R. L., K. R. McLeod, J. L. Klotz, and R. N. Heitmann. 2004. Rumen development, intestinal growth and hepatic metabolism in the pre- and postweaning ruminant. J. Dairy Sci. 87 (E Suppl.):E55-E65.

Davis, C. L., and J. K. Drackley. 1998. The Development, Nutrition, and Management of the Young Calf. Iowa State University Press, Ames.

Dawson, D. P., J. L. Morrill, P. G. Reddy, H. C. Minocha, and H. A. Ramsey. 1988. Soy protein concentrate and heated soy flours as protein sources in milk replacer for preruminant calves. J. Dairy Sci. 71:1301-1309.

Drackley, J. K., R. M. Blome, K. S. Bartlett, and K. L. Bailey. 2006. Supplementation of $1 \%$ L-Glutamine to milk replacer does not overcome the growth depression in calves caused by soy protein concentrate. J. Dairy Sci. 89:1688-1693.

Gardner, H. W., M. G. Shupe, W. Brimhall, and D. J. Weber. 1990. Causes of adverse responses to soybean milk replacers in young calves. J. Dairy Sci. 73:1312-1317.

Heinrichs, A. J., and K. E. Lesmeister. 2005. Rumen development in the dairy calf. Pages 53-66 in Calf and Heifer Rearing. P. C. Garnworthy, ed. Nottingham Univ. Press., Nottingham, UK.

Iranian Council of Animal Care. 1995. Guide to the Care and Use of Experimental Animals, vol. 1. Isfahan University of Technology, Isfahan, Iran. 
Kilshaw, P. J., and H. Slade. 1982. Villus atrophy and crypt elongation in the small intestine of preruminant calves fed with heated soyabean flour or wheat gluten. Res. Vet. Sci. 33:305-308.

Lallès, J. P., R. Toullec, P. Bouchez, and L. Roger. 1995a. Antigenicity and digestive utilization of four soya products by the preruminant calf. Livest. Prod. Sci. 41:29-38.

Lallès, J. P., R. Toullec, P. Branco Pardal, and J. W. Sissons. 1995b. Hydrolyzed soy protein isolate sustains high nutritional performance in veal calves. J. Dairy Sci. 78:194-204.

Maiga, H. A., D. J. Schingoethe, F. C. Ludens, W. L. Tucker, and D. P. Casper. 1994. Response of calves to diets that varied in amounts of ruminally degradable carbohydrate and protein. J. Dairy Sci. 77:278-283.

NRC. 2001. Nutrient requirements of dairy cattle. Pages 214-233 in Nutrient Requirements of Young Calf. 7th rev. ed. Natl. Acad. Sci., Washington, DC.

NutritionData. 2007. CondéNet Inc. http://www.nutritiondata.com Accessed July 20, 2007.

Ramsay, H. A., and T. R. Willard. 1975. Soy protein for milk replacers. J. Dairy Sci. 58:436-441.

Sander, E. G., R. G. Warner, H. N. Harrison, and J. K. Loosli. 1959. The stimulatory effect of sodium butyrate and sodium propionate on the development of rumen mucosa in the young calf. J. Dairy Sci. 42:1600-1605.

SAS Institute Inc. 2003. Version 9.1. Edition. SAS Institute Inc., Cary, NC.
Silva, A. G., J. T. Huber, T. H. Herdt, R. Holland, R. M. Degregorio, and T. P. Mullaney. 1986. Influence of substituting two types of soybean protein for milk protein on gain and utilization of milk replacers in calves. J. Dairy Sci. 69:172-180.

Sissons, J. W., A. Nyrup, P. J. Kilshaw, and R. H. Smith. 1982. Ethanol denaturation of soyabean protein antigens. J. Sci. Food Agric. 33:706-710.

Sissons, J. W., R. H. Smith, and D. Hewitt. 1979. The effect of giving feeds containing soya-bean meal treated or extracted with ethanol on digestive processes in the preruminant calf. Br. J. Nutr. 42:477-485.

Tomkins, T., J. Sowinski, and J. K. Drackley. 1994. New developments in milk replacers for pre-ruminants. Pages 71-90 in Proc. 55th Minnesota Nutr. Conf. Univ. St. Paul, MN

Van Soest, P. 1994. Nutritional Ecology of the Ruminants. 2nd ed. Cornell University Press, Ithaca, NY.

Van Soest, P. J., J. B. Robertson, and B. A. Lewis. 1991. Methods for dietary fiber, neutral detergent fiber, and nonstarch polysaccharides in relation to animal nutrition. J. Dairy Sci. 74:35833597.

Wang, Z., and L. A. Goonewardene. 2004. The use of mixed models in the analysis of animal experiments with repeated measures data. Can. J. Anim. Sci. 84:1-11.

Yaghoubi, S. M. J., G. R. Ghorbani, H. R. Rahmani, and A. Nikkhah. 2007. Growth, weaning performance, and blood indicators of humoral immunity in Holstein calves fed flavonoids. J. Anim. Physiol. Anim. Nutr. doi:10.1111/j.1439-0396.2007.00734.x 